\title{
О НЕКИМ АСПЕКТИМА ЦРКВЕНОГ АДМИНИСТРАТИВНОГ СТИЛА
}

\section{Сажетак}

у овоме раду настојаћемо да сагледамо административна документа у сфери сакралне комуникације, сабраних у књизи Уредбе и прописи Митрополије београдске: 1857-1876, са становишта њихових најбитнијих конститутивних елемената. Конкретно, описаћемо њихове садржинске и функционалне одлике, идентификоваћемо елементе разних нивоа који конституишуњихов језичко-стилски израз, као и најмаркантнија стилска изражајна средства која су им својствена.

Кључне речи: теолингвистика, сакрална комуникативна култура, административни стил, стилистика, Уредбе и прописи.

Сакрални функционалностилски комплекс обухвата следеће стилове: теолошки научни стил, административно-пословни стил, информативно-публицистички стил и разговорни стил у унутарцрквеној комуникацији (Кончаревић 173-177). У даљем излагању представићемо административно-пословни стил, његов екстралингвистички оквир и интралингвистичке доминанте.

Административно-пословни стил у сфери деловања Цркве опслужујесферуаминистративно-правниходносаунутарорганизације и устројства Цркве, као и регулативе односа Црква - држава. Он се реализује искључиво у писаној форми, а у његовом саставу издваја се неколико подстилова (Кончаревић 178): а) законодавно-правни у ужем смислу (закони, прописи, правила, уредбе, укази, законски 
прописи у сфери црквеног и црквено-грађанског права, акта канонског права, статути црквених органа и организација, дисциплинарни типици, резолуције црквених скупова и др.); б) административноканцеларијски (акта, одлуке, пословни документи, изјаве, пуномоћја и др.) и в) дипломатски (протоколи, уговори, коминикеи, споразуми, конвенције, меморандуми и др.); г) индивидуално-потврдни (везан за делатност клирика и лаика у Цркви: аутобиографије, дипломе, сведочанства, уверења, потврде, карактеристике, препоруке, исповедна писма и др.) и д) кореспонденцијски (писма, молбе, жалбе, извештаји, шематизми, захтеви, позиви, пуномоћја и др.).

Основне одлике административно-пословног стила јесу прецизност излагања, која не допушта могућност двојаког тумачења, детаљност, стереотипност и стандардизованост у исказивању садржине и директивни карактер поруке. Језик административних и правних докумената изискује пре свега прецизност и немогућност невалидних или различитих - алтернативних или међусобно искључивих - тумачења. Ове црте налазе одраз не само у систему језичких средстава него и у екстралингвистичким начелима обликовања конкретних административно-правних текстова - у њиховој структури, композицији и рубрикацији (Кончаревић 174).

Овај радјепосвећен сагледавањуусфери сакралне комуникације административних докумената сабраних у књизи Уредбе и прописи Митрополије београдске: 1857-1876 (Ранковић и Лазић). Изворни документи публиковани у наведеној књизи смештени су у архиву Епархије браничевске у Пожаревцу. Потичу из периода када је Пожаревац био седиште Пожаревачког протопрезвитерата који је, као мања црквено-управна јединица, био у саставу Митрополије београдске. Изворна грађа садржи уредбе, прописе, правила као и решења Архијерејских Сабора које је Митрополија београдска, преко окружних протопрезвитера, прослеђивала подручном свештенству. Сагледавајући садржину и структуру публикованих извора, уочава се широк спектар тема који се дотичу, не само оних из црквене, већ и из социјалне, политичке и културне историје (Ранковић и Лазић 15-16).

Типологију Уредаба и прописа Митрополије београдске можемо извести према више параметара: адресанту, адресату, тематици и циљу. 
Анализирани документи имају појединачног адресанта - духовно лице у чину архијереја или свештеника (углавном је то Архиепископ београдски и митрополит српски - уз чести додатак „благожелателни“, јавља се и архијереј који га замењује „привремено извршуюћи дужность"), одговорно лице у име Конзисторије (председник („предсьдатель“ и „председникь“), секретар, протоколиста или члан), министра („Министар просвете и Црквених дела“) и одговорно лице Одбора за помоћ ратних страдалника („председник Одбора“).

По адресату сви документи се могу поделити на „унутарцрквене“ и „изванцрквене“. Као адресати „унутарцрквених“ докумената јављају се а) лица, односно, свештенство (оно се јавља само са титулатуром: честнБйшій намьстникъ, благоговьйный намБстникъ, благоговьйньйшій протоєрей, пречестньйш. госп. протоєрей, пречастњејши протојереј, благоговьйны Іерей, честньйшій Іерей) и лаици (пречестньйшій господине), и б) Конзисторија (Конзисторији Епархије Београдске). Као адресат „изванцрквених“ докумената наводи се само једно од државних министарстава (Министерству Просвете и Црквены Дьла).

Сагледавајући структуру и садржину анализираних докумената, уочава се широк спектар тема којих се дотичу, не само оних из црквене, већ и социјалне, политичке и културне историје. Свакако, највећи број докумената односи се на организационо устројство и црквеноадминистративно уређење Српске Православне Цркве у Кнежевини Србији, као и утврђивање верског и црквеног живота у складу са актуелном богословском и литургичком литературом, коју је Конзисторија редовно препоручивала свештенству путем расписа. Поред докумената који се тичу унутрашњег уређења Цркве, значајно место заузимају и циркулари захваљујући којима се на прави начин може сагледати просветно-едукативна улога Цркве у конституисању индивидуалног и колективног идентитета српског друштва XIX века. У оквиру државног програма систематске верске и културно-просветне едукације, држава је преко Цркве као институције, која је, бринући о утврђивању вере и морала у народу, као залоге за духовни и материјални просперитет нације, имала ангажовану улогу и у свеопштем просвећивању поданика - од политичке и друштвене едукације до подизања нивоа 
свести о потреби одржавања хигијене и народног здравља. Пажње вредне документе представљају они који осветљавају однос Цркве према држави и владарима, међу којима посебно место имају они у којима се потврђује божанска ауторизација владарске власти кроз миропомазање и литургијско помињање. С друге стране, држава је такође у Цркви видела и снажан интегративни фактор у изградњи националног идентитета и утврђивање ауторитета сопствене власти. Тако је након политичких потреса и промена владара на престолу у Кнежевини Србији, у тренутку када је требало учврстити позиције и успоставити пољуљани ауторитет власти, Митрополија београдска, као највиша црквена институција у Кнежевини Србији, под непосредним надзором државе редовно упућивала наредбе свештенству у којима се позивало на верност и послушност владајућој династији и постојећем државно-правном поретку. Поред тога, известан број докумената дотиче се српског духовног и културног наслеђа, сагледано, пре свега, из перспективе донетих законских аката на основу којих је било регулисано подизање и опремање цркава и манастира у Кнежевини Србији (о садржини докумената видети Ранковић и Лазић 5-13).

По своме циљу анализирана документа могу се поделити на информационе, дидактичке и епидеиктичке. Информациона документа имају за циљ да информишу црквене служитеље, а преко њих и вернике, о најважнијим догађајима Цркве и државе, дидактичка имају за циљ да на приступачан начин објасне најважније аспекте православне верске доктрине, док епидеиктичка документа позивају на прослављање значајних догађаја, како из живота Цркве, тако из државне и јавне сфере (празници црквеног годишњег круга, хиротоније или рукоположења, прославе рођендана владара).

Изворни документи, настали до краја седме деценије XIX века, исписани су старом азбуком, односно, грађанским писаним типом ћирилске азбуке, обогаћеном, истина ретко, словима карактеристичним за српске гласове. Другим речима, ћирилска графија ових докумената је у низу својих особина традиционално славеносрпска, али и прогресивна, са упрошћеном графијом. Почетком осме деценије XIX века настају документи исписани, уз извесна одступања, Вуковом азбуком. Подсећања ради, Књажеско-српска канцеларија је 1832. објавила забрану штампања књига Вуковом азбуком (текст забра- 
не види: Младеновић 473-475). У Србији је забрана употребе Вукове азбуке укинута 1859/60. године, 1865. она је прихваћена на Великој школи, а тек 1868. уклоњено је последње ограничење за њену употребу. У публикацији, текст изворних докумената дат је у транслитерисаном облику, односно, изворне графеме доследно су транспоноване графемама исте звучне вредности. Правопис докумената је несређен и колебљив. Одсуство општеприхваћених правила писари су искористили тако да је сваки стварао свој правопис или писао без икаквих правила. Извесни словни знаци, интерпункција и пунктуација понекад су употребљени у зависности од процене писара (Ранковић и Лазић 16-17; Ранковић 465-472).

Основни лексички фонд изворних докумената углавном је српски. Српском народном језику недостајали су изрази за многе апстрактне појмове, као и за тековине новије цивилизације (Ивић и Кашић 311-380). Такви недостаци били су попуњавани речима из рускословенског, руског, славеносрпског, немачког, француског, уколико нису преузимани интернационализми или колоквијализми (Ранковић и Лазић 17).

С тачке гледишта лексичке семантике, стилске одлике текста Уредаба и прописа Митрополије београдске огледају се пре свега у интензивном присуству јединица тематске групе „православна сакрална лексика“, које се могу класификовати у следеће групе: а) теоними и агионими; б) фундаментални богословски појмови; в) називи степена црквене јерархије мирског и монашког реда; г) Свете Тајне и свештенодејства, облици и елементи богослужења; д) делови и ентеријер храма; ђ) речи и изрази који означавају деловање и појаве у животу православног свештенства и верника; е) свештеничке одежде; ж) богослужбени предмети и црквени сасуди и утвари; з) елементи црквеног календара и црквени празници и појмови годишњег богослужбеног круга; и) називи елемената система духовног образовања; ј) устаљени изрази, фразеологизми, ситуативни и етикецијски клишеи из унутарцрквене комуникације.

С тачке гледишта стилске обојености јединица које конституишу документе Уредаба и прописа Митрополије београдске може се издвојити неколико стилских стратума: неутрални, сакрални, књишки и разговорни. Неутрална лексика врши функцију неутралног лексич- 
ког оквира, њима је својствена нулта функционалностилистичка маркираност и не одликују се емоционално-експресивном обојеношћу. Како она не пружа конкретну представу о тематици или садржини Уредаба и прописа Митрополије београдске, ту функцију врши стилски маркирана лексика - сакрална, књишка и разговорна. Може се рећи да категорија сакралне лексике има улогу главног стилистичког маркера сваког религијског жанра, па тако и ових докумената.

Група лексике са књишком обојеношћу омогућава стварање једне посебне, узвишене тоналности појединих „административних“ докумената. У питању су углавном лексеме са творбеним елементима преузетим из рускословенског или српскословенског језика. Међу њима има архаичних деривата са суфиксима -ство: свидБтелство, предстателство, свештенодьйство, правителство; -аније/-еније: страхопочитаніє, благодарение, крещеніє, сохраненіє, прошеніє; -ствије/-стије: молебствіє, благочестіє; -тељ: Спасительмъ. Јављају се сложенице са формантима благо-: благословъ, благоволила; бого: богомоля.

У изворним документима јављају се деривати са префиксима који нису карактеристични за општеупотребни језик. Тако, уместо префикса вb-, въ-, $\mathrm{cb}^{-}, \mathrm{cb}-$ и въз- најчешће се срећу примери у рускословенском фонетском лику во-, со-, воз-: предъ Воскресеніємъ, вовьреннымъ, на Воведенїе, содержава се, собрано буде, соотечественнике наше, соборно, телесногъ состава, соразмьрно, возда, возносити, воду возлива, свога возраста. Срећу се и примери: вдову (парохію), при входу. Српскословенски префикс са- среће се у мањем броју примера у односу на рускословенски рефлекс: сабранноме, сачине, саблазнь, садржанія, саобштаваюћи, саобштаваю се, сажителство. Предлози са рускословенским фонетским ликом чешћи су у односу на српскословенске: во Діакона, во Хрість, ко предохраненію, ко исполненію. Са српскословенским фонетизмом среће се предлог са: са тымъ, са своима, са парохіянима. Са аспекта стилистике, важно је напоменути да се у једном истом документу или код једног писара могу срести, чак и у истој реченици, елементи како српскословенског тако и рускословенског: са страхомъ и сокрушенымъ сердцемъ.

Исто тако, уочавамо да је у овим административним документима, поред лексема које означавају апстрактне појмове и духовне 
реалије, присутан и део лексема и синтагми информативно-публицистичке провенијенције, нарочито уколико је њихова садржина усмерена на на интерпретацију актуелних црквених и друштвених збивања и процеса. Тако, рецимо, митрополит Београдски Михаило обавештава о одлагању почетка нове школске године у Богословији због ратног стања: „Збогъ ратногъ станя коє постои у Београду отложенъ $€$ почетакъ школе у Семинаріи, коіой є зданіє одъ градских топова оштећено и іошъ неоправльно“ (Ранковић и Лазић 146). Или, када Конзисторија издаје наредбу да свештенство престане да помиње кнегињу Јулију на Литургији: „Ньгова Свьтлость Князъ Србіє и Господаръ Михаилъ Обреновићъ III. изявіо $\epsilon<. . .>$ свою желю, да се Ньна Свьтлость Госпођа Княгиня Юлія неспоминь више у црквама ни изван цркве на Єктеніяма“ (Ранковић и Лазић 200). Или, када Архијерејски Сабор позива на поштовање вере и морала: „И у друштвама фамилијарним, по јавним зборовима и публичним местима воде се без сваког обзира и уздржавања такви разговори који обарају свако поштовање вере, цркве и светиње народне. Млоги налазе у томе славу да поколебају код простосрдачних верни срца уважење и поједини истина вере и у опште веру исмевајући и спољашњу страну и унутрашњи њен значај“ (Ранковић и Лазић 277). Или, када архијерејска власт позива подручно свештенство да прикупља помоћ за рањенике: „А спомените се ратних бораца, који излажу свој живот за свету веру и отечество и допадају у борби с непријатељем ране. Зар можемо да мимо тих нама драгих рањеника прођемо равнодушни, и да се не сажалимо и да им не притекнемо у помоћ, као што је Самарјанин еванђелском рањенику" (Ранковић и Лазић 308)?

Изнесеним стилским цртама не исцрпљује се списак лингвостилистичких истраживања особина типичних за црквено-административни стил. И поред тога, могу се извести извесни закључци који би поставили темељ за даља истраживања једног од стилова сакрума.

Административно-пословни стил у сфери деловања Цркве опслужује сферу аминистративно-правних односа унутар организације и устројства Цркве, као и регулативе односа Црква држава. Он се реализује искључиво у писаној форми, а у његовом саставу издваја се неколико подстилова. Основне одлике административно-пословног стила јесу прецизност излагања, која не допушта 
могућност двојаког тумачења, детаљност, стереотипност и стандардизованост у исказивању садржине и директивни карактер поруке. Типологију Уредаба и прописа Митрополије београдске извели смо према више параметара: адресанту, адресату, тематици и циљу. Анализирани документи имају појединачног адресанта - духовно лице у чину архијереја или свештеника, одговорно лице у име Конзисторије, министра и одговорно лице Одбора за помоћ ратних страдалника. По адресату сви документи се могу поделити на „унутарцрквене“ и „изванцрквене“. Сагледавајући садржину и структуру публикованих извора, уочава се широк спектар тема који се дотичу, не само оних из црквене, већ и из социјалне, политичке и културне историје. По своме циљу анализирана документа могу се поделити на информационе, дидактичке и епидеиктичке. Основни лексички фонд изворних докумената углавном је српски. Српском народном језику недостајали су изрази за многе апстрактне појмове, као и за тековине новије цивилизације, који су били попуњавани речима из рускословенског, руског, славеносрпског, немачког, француског, уколико нису преузимани интернационализми или колоквијализми. С тачке гледишта лексичке семантике, стилске одлике текста Уредаба и прописа Митрополије београдске огледају се пре свега у интензивном присуству јединица тематске групе „православна сакрална лексика“, а са становишта стилске обојености јединица које конституишу документе Уредаба и прописа Митрополије београдске може се издвојити неколико стилских стратума: неутрални, сакрални, књишки и разговорни.

\section{Литература}

Ивић, Павле и Кашић Јован. „О језику код Срба у раздобљу од 1804. до 1878. Године“. Историја српског народа, V/2, Београд: Српска књижевна задруга, 1981, 311-380. Принт.

Кончаревић, Ксенија. Поглед у теолингвистику. Београд: Јасен, 2015. Принт.

Младеновић, Александар. Историја српског језика. Одабрани радови. Београд: Чигоја штампа, 2008. Принт.

Ранковић, Зоран и Лазић Мирослав. Уредбе и прописи Митрополије београдске 1857-1876. Приредили Зоран Ранковић и Мирослав Лазић. Библиотека Архива Епархије браничевске. Књига 2. Пожаревац: Епархија браничевска, 2010. Принт. 
Ранковић, Зоран. „Графијска и ортографско-фонетска обележја Уредаба и прописа Митрополије београдске“. Теолингвистичка проучавања словенских језика: зборник. Ур. Јасмина Грковић-Мејџор и Ксенија Кончаревић. Београд: САНУ, 2013, 465-472. Принт.

\section{Ivana Knežević \\ Zoran Ranković \\ Field of Theology}

\section{ON SOME ASPECTS OF THE CHURCH ADMINISTRATIVE STYLE}

\section{Summary}

In this paper we will try to study administrative documents in the sphere of religious communication, collected in the book of The Rules and Regulations of the Metropolitanate of Belgrade: 1857-1876, in the terms of their most important constituent elements. We shall particularly pay attention to their content and functional characteristics and we shall try to identify elements of various levels that constitute their linguistic and stylistic expression, as well as the most striking stylistic means of expression that are inherent to them.

Key words: theolinguistics, sacral communicative culture, administrative style, stylistics, rules and regulations. 